\title{
Wpływ przewlekłej stymulacji prawej komory - aspekty elektrofizjologiczne, neurohumoralne, histopatologiczne i hemodynamiczne
}

\section{Effect of chronic right ventricular pacing - electrophysiological, neurohumoral, histopathological, and hemodynamic aspects}

\author{
Leszek Chęciński ${ }^{1}$, Agnieszka Sławuta ${ }^{2}$, Joanna Moszczyńska-Stulin ${ }^{1}$, \\ Caroline Chęcińska ${ }^{3}$, Jacek Gajek ${ }^{4}$
}

\author{
${ }^{1}$ Klinika Kardiologii Uniwersyteckiego Szpitala Klinicznego im. Jana Mikulicza-Radeckiego we Wrocławiu \\ ${ }^{2}$ Oddział Kardiologii Szpitala w Kłodzku, ZOZ Kłodzko \\ ${ }^{3}$ Oddział Dziecięcy Szpitala w Oławie, ZOZ Oława \\ ${ }^{4}$ Katedra i Klinika Kardiologii Uniwersytetu Medycznego we Wrocławiu
}

\section{Streszczenie}

Pacjenci z objawową dysfunkcją węzła zatokowego to stosunkowo liczna grupa chorych, którzy, ze względu na nasilone objawy kliniczne, są poddawani zabiegowi implantacji stymulatora serca. Aktualna wiedza medyczna z dystansem odnosi się do korzyści ze stosowania stałej stymulacji serca w tej grupie chorych, zwłaszcza jeżeli rozpatruje się jej wpływ na ogólną przeżywalność pacjentów. Bezdyskusyjny pozostaje fakt korzystnego wpływu stymulacji na ograniczenie zgłaszanych przez pacjentów objawów klinicznych. Należy ze szczególną starannością kwalifikować pacjentów do tej formy terapii, a tym samym w sposób racjonalny zbilansować zyski wynikające ze stosowania elektrostymulacji z ewentualnymi niekorzystnymi następstwami, będącymi efektem przewlekłej stymulacji serca.

Pacjenci poddani przewlekłej stymulacji prawokomorowej wykazują zmiany struktury histologicznej mięśnia sercowego, zaburzenia przepływu krwi w miokardium oraz aktywację czynników neurohumoralnych, których nasilenie może indukować zmiany degeneracyjne i pogarszać funkcję rozkurczową i skurczową serca. Zmiany te dotyczą zwłaszcza chorych z wyjściowo upośledzoną funkcją lewej komory.

Ponieważ w wielu badaniach wskazywano na niekorzystny odległy efekt stymulacji prawokomorowej oraz ze względu na wprowadzenie elektrod o aktywnej fiksacji, to już w latach 90. XX wieku zaczęto poszukiwać nowych miejsc lokalizacji elektrody komorowej służących zapewnieniu jak najbardziej zbliżonego do fizjologicznego toru depolaryzacji komór. Podjęto próby kliniczne zmierzające do wskazania alternatywnych miejsc stymulacji serca związanych z mniejszym niekorzystnym wpływem na funkcję serca, zarówno w odniesieniu do położenia samej elektrody stymulującej, jak i odsetka stymulacji komorowej. Dlatego redukcja prawokomorowej stymulacji do niezbędnego minimum poprzez promowanie własnego przewodzenia przedsionkowo-komorowego - za pomocą właściwie zaprogramowanej histerezy lub czasu opóźnienia przedsionkowo-komorowego - stanowi jeden z elementów ograniczenia późnych następstw stymulacji.

Na podstawie licznych pozycji piśmiennictwa autorzy wskazują na możliwości uniknięcia niekorzystnych właściwości przewlekłej prawokomorowej stymulacji serca dostępnymi obecnie technikami stymulacji i sposobami implantacji elektrod.

Słowa kluczowe: stała stymulacja serca, stymulacja drogi odpływu prawej komory, zespół stymulatorowy, alternatywne miejsca stymulacji komorowej

(Folia Cardiologica 2015; 10, 6: 410-417)

Adres do korespondencji: lek. Leszek Chęciński, Klinika Kardiologii, Uniwersytecki Szpital Kliniczny im. Jana Mikulicza-Radeckiego, ul. Borowska 213, 50-556 Wrocław, email: checinski_leszek@tlen.pl 


\section{Wstęp}

Pacjenci z objawową dysfunkcją węzła zatokowego (SND, sinus node dysfunction) to stosunkowo liczna grupa chorych, którzy - ze względu na nasilone objawy kliniczne - są poddawani zabiegowi implantacji stymulatora serca. Aktualna wiedza medyczna z dystansem odnosi się do korzyści ze stosowania stałej stymulacji serca w tej grupie chorych, zwłaszcza jeżeli rozpatruje się jej wpływ na ogólną przeżywalność pacjentów [1]. Bezdyskusyjny pozostaje fakt korzystnego wpływu stymulacji na zmniejszenie zgłaszanych przez pacjentów objawów klinicznych. W związku z wyborem dwujamowej stymulacji w tej grupie chorych, między innymi ze względu na współistniejące zaburzenia przewodzenia przedsionkowo-komorowego, które u części pacjentów z czasem mogą generować istotny problem kliniczny, prowadzi do stymulacji prawej komory. Z założenia u części pacjentów, którzy a priori nie wymagają stymulacji komorowej, w wyniku wydłużonego czasu przewodzenia przedsionkowo-komorowego uniemożliwiającego wykorzystanie istniejących algorytmów zapobiegających niechcianej stymulacji DDD, doprowadza się do stymulacji dwujamowej. Kwalifikując chorych do implantacji układu stymulującego, nalezy mieć świadomość, że u części z nich będzie się trzeba zmierzyć z następstwami przewlekłej stymulacji, zwłaszcza stymulacji prawej komory mięśnia sercowego.

\section{Niekorzystny wpływ stymulacji prawej komory serca}

Na początku XX wieku Carl J. Wiggers, na podstawie przeprowadzonych badań na zwierzętach, wykazał upośledzenie funkcji mechanicznej lewej komory podczas prawokomorowej stymulacji serca. Uznał, że jest to efekt znacznie wolniejszego przewodzenia mięśniowego, w odróżnieniu od szybkiej i fizjologicznej komorowej aktywacji miokardium za pośrednictwem prawidłowego układu bodźcoprzewodzącego, jaka zachodzi podczas rytmu zatokowego lub stymulacji przedsionka [2]. W wyniku długotrwałej stymulacji serca dochodzi do niekorzystnych zmian strukturalnych w kardiomiocytach, w tym do asymetrycznego przerostu mięśnia lewej komory lub jej rozstrzeni [3]. Poza tym zwiększa się stężenie katecholamin w sercu [4] i dochodzi do zaburzenia układu włókien mięśniowych [5, 6]. Prawokomorowa kardiostymulacja wpływa na zmiany histopatologiczne w mięśniu sercowym, doprowadza do zwłóknienia śródmiąższowego, nacieku mięśnia przez tkankę tłuszczową oraz zróżnicowania wymiarów kardiomiocytów [7, 8]. Odcinkowa przebudowa serca (tzw. remodeling) jest następstwem hipertrofii włókien w jednym, a ich zanikiem w innym rejonie oraz zmianą w przestrzennym układzie włókien mięśniowych [6, 9]. Asynchroniczny skurcz miocytów prowadzi do odcinkowych zmian w przepływie krwi przez poszczególne warstwy mięśniówki serca, co wywołuje miejscową modyfikację w zakresie dostępu i zużycia tlenu oraz wychwytu glukozy. Nierzadko stwierdza się regionalne zaburzenia kurczliwości mięśnia sercowego obejmujące najczęściej ścianę dolną, okolicę koniuszka i przegrodę międzykomorową. Poza tym zmianie ulega ekspresja białek oraz przepływ prądów jonowych [4, 10, 11]. W obszarach ulegających aktywacji pod wpływem stymulacji dochodzi do zmniejszenia przepływu wieńcowego oraz redukcji konsumpcji tlenu przez mięsień sercowy o około 30\% [12]. Zmniejsza się objętość wyrzutowa (SV, stroke volume) przy zwiększonym lub niezmienionym zużyciu tlenu $[13,14]$.

Na podstawie przeprowadzonych badań Badke i wsp. wykazali [15], że prawokomorowa stymulacja serca, w porównaniu ze stymulacją przedsionkową, wywołuje spadek szybkości narastania ciśnienia w lewej komorze i regionalne zaburzenia skracania, co w konsekwencji zmienia geometrię skurczu i upośledza efekt hemodynamiczny. W opublikowanym badaniu WHERE dowiedziono, że trwająca 6 miesięcy stymulacja komorowa obniża jakość życia, zmniejsza frakcję skracania i prowadzi do zwiększenia późnorozkurczowego wymiaru lewej komory w odniesieniu do wartości wyjściowych [16]. Poza tym stwierdzono, że paradoksalny ruch przegrody międzykomorowej wywołany przez asynchroniczną aktywację lewej komory prowadzi do nieskoordynowanego skurczu mięśni brodawkowatych, co może być przyczyną nasilenia lub powstania skurczowej, czynnościowej niedomykalności zastawki dwudzielnej [17-19].

W wyniku kardiostymulacji dochodzi do asynchronicznej aktywacji mięśnia lewej komory, analogicznie jak w bloku lewej odnogi pęczka Hisa (LBBB, left bundle branch block). Grines i wsp. [20] dowiedli, że u pacjentów z zaburzeniami przewodzenia śródkomorowego o morfologii LBBB, w porównaniu z chorymi bez stwierdzanego LBBB, dochodzi do upośledzenia skurczu przegrody międzykomorowej z następczym obniżeniem frakcji wyrzutowej (EF, ejection fraction). Poza tym czas napełniania lewej komory ulega istotnemu skróceniu [20]. Podobne wnioski sformułowali Verna i wsp. [21], którzy stwierdzili mniejsze wartości EF u pacjentów stymulowanych w trybie VAT niż u chorych stymulowanych w trybie AAl lub u pacjentów z zachowanym rytmem zatokowym. W ocenie badaczy niższe wartości EF w trakcie stymulacji prawokomorowej są efektem asynchronii skurczu obu komór [21].

Pogorszenie funkcji hemodynamicznej serca może być następstwem braku synchronii międzykomorowej i/lub przedsionkowo-komorowej. W eksperymentalnym badaniu Boertha i Covella [22] wykazano, że zmiana sposobu stymulacji z przedsionkowej na komorową powoduje znamienne obniżenie wartości skurczowego ciśnienia tętniczego w następstwie asynchronicznego skurczu komór w takcie prawokomorowej stymulacji serca. Rosenquist i wsp. [23] dokonali oceny kurczliwości regionalnej i globalnej mięśnia 
sercowego u pacjentów stymulowanych w trybach VVI, AAI i DDD. Na podstawie wyników badań stwierdzili większe nasilenie upośledzenia EF u chorych stymulowanych w trybie VVI [23]. W badaniu Bedotto i wsp. [24] opisano niekorzystny wpływ stymulacji sekwencyjnej na funkcję rozkurczową i skurczową lewej komory. Stopień progresji dysfunkcji jest tym większy, im bardziej jest nasilone wyjściowe upośledzenie EF [24].

Duży odsetek stymulacji koniuszka prawej komory wiąże się ze wzrostem częstości występowania lub pogorszeniem uprzednio już istniejących objawów niewydolności serca. Podstawą powyższych wniosków są wyniki badania DAVID (Dual Chamber and VVI Implantable Defibrillator) opublikowanego w 2002 roku. Włączono do niego 506 pacjentów z wyjściowo upośledzoną EF (średnia wartość 27\%), którym wszczepiono dwujamowy kardiowerter-defibrylator w ramach pierwotnej lub wtórnej prewencji nagłej śmierci sercowej. Pacjentów w sposób losowy przydzielono do dwóch grup - pierwszą stanowili chorzy stymulowani w trybie DDDR 70/min, a drugą pacjenci z zaprogramowaną stymulacją w trybie VVI 40/min. Zaobserwowano, że zwiększony odsetek stymulacji prawej komory jest przyczyną wzrostu liczby hospitalizacji z powodu zaostrzenia niewydolności serca $[25,26]$.

\section{Zespół stymulatorowy}

U niektórych chorych, głównie z okresową stymulacją komorową w trybie VVI, mogą wystąpić niepożądane objawy kliniczne, określane jako zespół stymulatorowy (PS, pacemaker syndrome). Zespół ten najczęściej powstaje w wyniku zachowanego wstecznego przewodzenia komorowo-przedsionkowego. Może być również efektem całkowitego rozkojarzenia przedsionkowo-komorowego w przypadku braku wstecznego przewodzenia z komór do przedsionków. Rozpoznanie ustala się na podstawie podawanych w wywiadzie objawów klinicznych, które są wynikiem obniżenia wartości skurczowego ciśnienia tętniczego o co najmniej $20 \mathrm{~mm}$ Hg podczas rytmu stymulowanego. Do najczęstszych symptomów należą: bóle i zawroty głowy, omdlenia, splątanie, uczucie zmęczenia (często nieadekwatnego do wykonanego wysiłku fizycznego), spoczynkowa lub wysiłkowa duszność niewiadomego pochodzenia, kołatanie serca, tętnienie w okolicy szyi. Poza tym pacjenci mogą zgłaszać typowe objawy dławicowe lub nietypowe bóle w klatce piersiowej, może pojawić się kaszel czy obrzęki kończyn dolnych, a w skrajnych przypadkach może wystąpić ostra niewydolności lewokomorowa pod postacią obrzęku płuc. Zespół stymulatorowy predysponuje do częstszego występowania migotania przedsionków, zwiększając tym samym odsetek powikłań zakrzepowo-zatorowych pod postacią naczyniopochodnych incydentów mózgowych. Stopień nasilenia objawów zależy zarówno od czasu trwania hipotonii tętniczej, jak i nasilenia spadku rzutu serca (CO, cardiac output) $[27,28]$.

Podłożem wystąpienia objawów PS jest zaburzona równowaga pomiędzy wpływem nerwu błędnego a napięciem układu współczulnego, co oddziałuje na regulację systemowego ciśnienia tętniczego. Zaburzona funkcja baroreceptorów zlokalizowanych głównie w zatokach tętnic szyjnych i w łuku aorty nie powoduje adekwatnego wzrostu całkowitego oporu obwodowego (TPR, total peripheral resistance) w odpowiedzi na obniżenie wartości ciśnienia tętniczego [29].

W warunkach fizjologicznych zmniejszone rzut i objętość wyrzutowa serca, które są następstwem komorowej kardiostymulacji, prowadzą do odruchowego zwolnienia częstotliwości wysyłania impulsów włóknami dośrodkowymi z baroreceptorów tętniczych do ośrodkowego układu nerwowego. Zlokalizowany w rdzeniu przedłużonym ośrodek naczynioruchowy, za pośrednictwem włókien współczulnych odśrodkowych, wywołuje wzrost napięcia naczyń tętniczych i żylnych. Poza tym, pod wpływem aktywacji sercowych włókien współczulnych i depresyjnego wpływu na sercowe odgałęzienia nerwu błędnego, zaopatrującego między innymi węzeł zatokowy, dochodzi do zwiększenia częstotliwości rytmu serca. Efektem końcowym jest wzrost wartości ciśnienia tętniczego [30].

Jednoczasowy skurcz przedsionków i komór przy zamkniętych zastawkach prawego i lewego ujścia żylnego może być efektem wstecznego przewodzenia komorowo-przedsionkowego. Powoduje to utratę czynności mechanicznej przedsionków w procesie napełniania komór - tym samym wtórnie dochodzi do spadku objętości wyrzutowej lewej komory ze wzrostem ciśnienia w kapilarach płucnych. Zwiększa się również ciśnienie w prawym i lewym przedsionku, żyłach głównych i płucnych. Prowadzi to do pobudzenia sercowo-płucnych mechanoreceptorów, w których rozpoczynają się dośrodkowe, bezmielinowe włókna nerwu błędnego. W efekcie dochodzi do pobudzenia dosercowych włókien nerwu błędnego oraz zahamowania włókien współczulnych serca i naczyń. W następstwie powyższej reakcji odruchowej następują wazodylatacja, zwolnienie częstości rytmu serca i obniżenie ciśnienia tętniczego [31].

Zwiększone napięcie mięśniówki serca powoduje wzrost wydzielania peptydu natriuretycznego - typu B (BNP, B-type natriuretic peptide) i przedsionkowego (ANP, atrial natriuretic peptide). Ostatecznie prowadzi to do zwiększenia wydzielania sodu i wody, inhibicji reniny i aldosteronu, spadku napięcia mięśniówki naczyń krwionośnych i zahamowania procesu włóknienia mięśnia sercowego [32, 33].

Wpływ stymulacji prawokomorowej omówiono w publikacji Kargula i wsp. [34]. Do badania włączono pacjentów z zespołem chorego węzła zatokowego (SSS, sick sinus syndrome), którym pierwotnie wszczepiono stymulator komorowy. Ze względu na obserwowane u tych chorych 
objawy zespołu stymulatorowego doszczepiono elektrodę i rozszerzono układ do funkcji stymulatora dwujamowego. U pacjentów jednoczasowo wykonano 24-godzinny pomiar ciśnienia tętniczego i monitorowanie elektrokardiograficzne metodą Holtera. Na podstawie przeprowadzonego badania stwierdzono znacznie większe spadki ciśnienia tętniczego w nocy w trakcie stymulacji VVI niż u pacjentów stymulowanych w trybie DDD [34].

W badaniu Boona i wsp. [35] wykazano podobne zależności między trybem stymulacji a obniżeniem wartości ciśnienia tętniczego. Podobnie jak w badaniach Kargula i wsp. zaobserwowano większe wahania ciśnienia tętniczego u pacjentów w trakcie stymulacji VVI niż stymulacji w trybie DDD [35]. Stewart i wsp. [36] udowodnili, że zmiana trybu stymulacji z synchronicznej dwujamowej DDD na komorową w trybie VVI powoduje zmniejszenie pojemności minutowej serca. Spadek ten zależy od obecności wstecznego przewodzenia komorowo-przedsionkowego i wynosi odpowiednio 30\%, natomiast u pacjentów bez wstecznego przewodzenia komorowo-przedsionkowego - 14\% [36].

\section{Badania kliniczne u chorych poddanych stymulacji serca}

Postępujący rozwój elektroterapii spowodował, że zaczęto zwracać uwagę nie tylko na wskazania i techniki implantacji kardiostymulatorów, ale również na stopień poprawy jakości życia oraz potencjalny, szkodliwy wpływ przewlekłej stymulacji serca. Przeprowadzono wiele badań klinicznych służących ocenie zależności między zastosowanym miejscem i trybem stymulacji a istotnymi punktami końcowymi, takimi jak śmiertelność, częstotliwość zdarzeń sercowo-naczyniowych, występowanie incydentów migotania przedsionków czy też wpływ na rozwój niewydolności serca.

W opublikowanym w 1997 roku badaniu klinicznym Danish Pacemaker Study autorstwa Andersena i wsp. [37] przeanalizowano grupę 225 pacjentów z SSS. Pacjentów poddano randomizacji do dwóch grup. Pierwsza z nich ( $n=110$ ) była stymulowana $w$ trybie AAl, natomiast druga grupa chorych $(n=115)-w$ trybie VVI. Na podstawie kilkuletniego okresu obserwacji wykazano znacznie większą częstotliwość występowania napadów migotania przedsionków, zdarzeń zakrzepowo-zatorowych, rozwoju niewydolności serca i wzrostu śmiertelności ogólnej u pacjentów poddawanych komorowej stymulacji serca [37].

W randomizowanym i prospektywnym badaniu PASE (PAcemaker Selection in the Elderly) porównano stymulację VVIR ze stymulacją w trybie DDDR. Oceniono 407 chorych w wieku 65 lat lub więcej, wśród których 175 pacjentów miało implantowany rozrusznik serca z powodu objawowej bradykardii w przebiegu SSS. U pozostałych chorych powodem wszczepienia stymulatora serca był przede wszystkim blok przedsionkowo-komorowy. Wszystkim osobom wszczepiono dwujamowy stymulator, a następnie w sposób losowy programowano stymulację do VVIR lub DDDR. Oceniano wpływ trybu stymulacji na śmiertelność ogólną, pierwszą hospitalizację z powodu niewydolności serca, zakończony lub niezakończony zgonem pierwszy incydent sercowo-naczyniowy, jakość życia oraz częstość występowania PS i napadów migotania przedsionków. Na podstawie trwającej kilkanaście miesięcy obserwacji wykazano poprawę jakości życia jedynie w grupie osób z SSS poddanych stymulacji dwujamowej. Na uwage zasługuje fakt, że u 26\% pacjentów zmieniono tryb stymulacji z komorowej na dwujamową z powodu objawów PS [38].

W 2000 roku Connolly i wsp. [39] przedstawili wyniki badania CTOPP (Canadian Trial of Physiologic Pacing), w którym stymulację DDDR lub AAIR porównywano ze stymulacją komorową VVIR. Efektem kilkuletniej pracy było wykazanie 24-procentowej redukcji występowania napadowego lub utrwalonego migotania przedsionków u chorych stymulowanych w trybie DDDR/AAIR [39].

W 2002 roku opublikowano wyniki badania MOST (MOde Selection Trial in sinus-node dysfunction), w którym przeanalizowano grupę 2010 pacjentów z SSS. Oceniano wpływ stymulacji DDDR, w porównaniu z VVIR, na ogólną śmiertelność, częstość występowania incydentów mózgowo-naczyniowych i migotania przedsionków oraz ryzyko hospitalizacji z powodu zaostrzenia niewydolności serca. Zaobserwowano mniejszą częstość występowania napadów migotania przedsionków i ograniczenie objawów niewydolności serca w grupie chorych stymulowanych fizjologicznie, tj. w trybie DDDR. Poza tym $40 \%$ pacjentów wymagało zmiany trybu stymulacji z komorowej na dwujamową z powodu obserwowanych objawów PS [40, 41]. Przeprowadzona przez Sweeneya i wsp. [42] analiza podgrupy 1339 pacjentów, których włączono do badania MOST, dowiodła, że wysoki odsetek stymulacji koniuszka prawej komory jest związany z większą częstością hospitalizacji z powodu nasilenia objawów niewydolności serca, i to niezależnie od trybu stymulacji.

W przeprowadzonym w grupie 2021 pacjentów badaniu UKPACE (United Kingdom Pacing and Cardiovascular Events) porównywano wpływ stymulacji DDD ze stymulacją VVI u chorych powyżej 70 lat wymagających wszczepienia rozrusznika serca z powodu bloku przedsionkowo-komorowego II i Ill stopnia. Wyniki tego randomizowanego badania nie wykazały istotnego statystycznie wpływu trybu stymulacji na śmiertelność całkowitą, liczbę zgonów z przyczyn sercowo-naczyniowych, epizodów migotania przedsionków, incydentów naczyniowo-mózgowych ani hospitalizacji z powodu objawów niewydolności serca [43, 44].

W 2011 roku opublikowano wyniki wieloośrodkowego badania klinicznego DANPACE (DANish Multicenter Randomised Trial on Single Lead Atrial PACing vs. Dual Chamber Pacing in Sick Sinus Syndrome), na podstawie którego nie wykazano istotnego wpływu trybu stymulacji na zmniejszenie śmiertelności całkowitej. Poza tym w analizowanych 
grupach chorych nie stwierdzono różnicy pod względem liczby zdarzeń mózgowo-naczyniowych ani stopnia nasilenia objawów niewydolności serca. Co ciekawe, stymulacja AAIR miała wręcz negatywny wpływ z powodu wzrostu częstości występowania napadów migotania przedsionków [45].

\section{Alternatywne miejsca stymulacji komorowej}

Ponieważ w wielu badaniach wskazuje się na niekorzystny odległy efekt stymulacji prawokomorowej, to zaczęto poszukiwać nowych miejsc fiksacji elektrody komorowej mających zapewnić jak najbardziej zbliżony do fizjologicznego tor depolaryzacji komór. Podjęto kliniczne próby zmierzające do wskazania alternatywnych miejsc stymulacji serca, które wiązałyby się z mniejszym niekorzystnym wpływem na funkcję serca - zarówno w odniesieniu do położenia samej elektrody stymulującej, jak i odsetka częstości stymulacji komorowej. Dlatego redukcja prawokomorowej stymulacji do niezbędnego minimum przez promowanie własnego przewodzenia przedsionkowo-komorowego - za pomoca właściwie zaprogramowanej histerezy lub czasu opóźnienia przedsionkowo-komorowego - stanowi jeden z elementów ograniczenia późnych następstw stymulacji [46].

Do najczęściej preferowanych alternatywnych miejsc stymulacji należy zaliczyć między innymi drogę odpływu prawej komory (RVOT, right ventricular outflow tract), przegrodę międzykomorową, okolicę lub bezpośrednią stymulację pęczka Hisa oraz dwukomorową stymulację serca (BiV, biventricular pacing). Stymulacja RVOT przyczynia się do poprawy parametrów hemodynamicznych, zwiększa napełnianie lewej komory oraz prowadzi do wzrostu objętości wyrzutowej, w porównaniu z klasyczną stymulacją koniuszka prawej komory [47]. Korzystny efekt stymulacji RVOT wykazano w wieloletnim, randomizowanym badaniu klinicznym przeprowadzonym przez Lewicką-Nowak i wsp. [48]. Mimo niewielkiej grupy badanych pacjentów zauważono istotną przewage stymulacji RVOT nad kardiostymulacją koniuszkową, która przyczyniała się do progresji niedomykalności zastawki trójdzielnej, pogorszenia funkcji skurczowej i rozkurczowej lewej komory oraz wzrostu stężenia N-końcowego propeptydu natriuretycznego typu B (NT-proBNP, N-terminal pro B-type natriuretic peptide) [48].

\section{Stymulacja pęczka Hisa}

W 2006 roku Occhetta i wsp. [49] opublikowali wyniki badania, w którym oceniono efekty stymulacji prowadzonej za pomocą elektrody umiejscowionej w okolicy pęczka Hisa. Do powyższego badania włączono 16 chorych z utrwalonym migotaniem przedsionków, u których przeprowadzono zabieg ablacji węzła przedsionkowo-komorowego, a następnie implantowano elektrodę do koniuszka prawej komory oraz w okolice pęczka Hisa. Na podstawie trwającej 6 miesięcy obserwacji stwierdzono poprawę wydolności fizycznej (ocenianej na podstawie klasyfikacji wg New York Heart Association [NYHA]), poprawę jakości życia oraz zmniejszenie niedomykalności zastawki dwudzielnej i trójdzielnej w grupie pacjentów poddanych stymulacji w okolicy pęczka Hisa [49].

Bezpośrednia stymulacja pęczka Hisa korzystnie wpływa na parametry hemodynamiczne serca zwłaszcza w grupie pacjentów z kardiomiopatią rozstrzeniową i utrwalonym migotaniem przedsionków. Powoduje zmniejszenie wymiaru późnorozkurczowego i późnoskurczowego lewej komory, zwiększa frakcję skracania oraz frakcję wyrzutową lewej komory (LVEF, left ventricular ejection fraction) [50].

\section{Stymulacja dwukomorowa}

W opublikowanym piśmiennictwie pojawiło się wiele doniesień potwierdzających korzystny wpływ stymulacji dwukomorowej, w porównaniu z tradycyjną stymulacją prawokomorową, w wybranych grupach pacjentów. Taka forma elektroterapii łagodzi objawy niewydolności serca i poprawia parametry hemodynamiczne lewej komory. Jest to zgodne z wynikami badania HOBIPACE, w którym dwukomorowa stymulacja serca istotnie zmniejszała końcowoskurczową i końcoworozkurczową objętość lewej komory oraz poprawiała jakość życia. Poza tym zwiększała wydolność fizyczną, EF oraz obniżała stężenie NT-proBNP [51]. Podobne były wyniki badania PAVE, w którym wykazano poprawe LVEF oraz wydolności fizycznej po zastosowaniu kardiostymulacji dwukomorowej [52].

W badaniu MADIT-CRT oceniano wpływ terapii resynchronizującej (CRT, cardiac resynchronization therapy) u chorych z rytmem zatokowym i niewydolnością serca. Do badania włączono 1820 pacjentów w I-II klasie czynnościowej według NYHA z LVEF nieprzekraczającą 30\% i szerokością zespołu QRS wynoszącą 130 ms lub więcej. Pacjentów poddano randomizacji do dwóch grup - grupe pierwszą stanowiły osoby, u których implantowano układ do terapii resynchronizującej z funkcją defibrylacji (CRT-D, cardiac resynchronization therapy defibrillator), natomiast w drugiej grupie chorym wszczepiano układ kardiowerter-defibrylator (ICD, implantable cardioverter defibrillator) bez funkcji resynchronizującej. Na podstawie obserwacji trwającej kilka miesięcy wykazano, że zastosowanie układu CRT-D prowadzi do zmniejszenia liczby hospitalizacji z powodu zaostrzenia objawów niewydolności serca, przy jednoczesnym braku wpływu na zmniejszenie śmiertelności całkowitej. Poza tym terapia ta wpływa korzystnie na parametry echokardiograficzne serca poprzez zmniejszenie objętości końcowoskurczowej i końcoworozkurczowej lewej komory oraz 12-procentowy wzrost LVEF [53].

Podobne wnioski wysnuto na podstawie badania klinicznego REVERSE, do którego włączono 610 pacjentów z niewydolnością serca w I-II klasie czynnościowej według NYHA, LVEF nie większą niż 40\% i szerokością zespołu QRS 
większą lub równą 120 ms. Wszystkim chorym wszczepiono układ CRT (z funkcją ICD lub bez niej), a następnie w sposób losowy przydzielono do grupy badanej lub kontrolnej. U pacjentów zakwalifikowanych do grupy badanej funkcja resynchronizacji była aktywna. Po trwającym 12 miesięcy okresie obserwacji wykazano istotny statystycznie spadek częstości hospitalizacji z powodu niewydolności serca oraz zmniejszenie objętości końcowoskurczowej lewej komory w grupie osób, u których funkcja CRT był aktywna. Nie stwierdzono natomiast istotnego wpływu na ograniczenie całkowitej śmiertelności [54]. Na podstawie powyższych badań obiecujące wydaje się wczesne zastosowanie CRT w celu spowolnienia postępu niewydolności serca.

\section{Podsumowanie}

Implantując pacjentom rozrusznik serca, trzeba mieć świadomość, że będą z niego korzystać przez następne lata.
Należy z niebywałą starannością kwalifikować pacjentów do tej formy terapii, a tym samym w sposób racjonalny zbilansować zyski wynikające ze stosowania elektrostymulacji z ewentualnymi stratami będącymi efektem przewlekłej stałej stymulacji serca. Niewątpliwym pozostaje fakt, że stały postęp elektroterapii (w tym techniki przeprowadzanych zabiegów oraz rozwój inżynierii biomedycznej) jest konieczny nie tylko z powodu zwiększającej się populacji chorych wymagających tej formy leczenia, ale również ze względu na potrzebę dostosowania się współczesnej medycyny do ewoluujących oczekiwań pacjentów. Konieczne jest dalsze prowadzenie badań w celu poszukiwania nowych, alternatywnych miejsc stymulacji, które w wybranych grupach chorych powinny być preferowane względem lokalizacji standardowej.

\section{Konflikt interesów}

Autorzy nie zgłaszają konfliktu interesów.

\section{Abstract}

Highly symptomatic patients with a sinus node disease constitute a relatively large group undergoing a permanent pacemaker implantation. There is no proof for lifesaving influence of this procedure. Nevertheless, the clinical symptoms decrease, with a simultaneous increase of patients' wellbeing. This symptomatic impact of permanent pacing is indisputable. However, a careful weighting of the indications to the pacemaker implantation is required in every patient to balance the benefits and disadvantages of a chronic heart stimulation.

The permanent right ventricle pacing contributes to unfavourable histological changes in the heart muscle structure, disturbed myocardial blood flow and neurohumoral activation, leading to degenerative processes interfering with diastolic and systolic functions of the ventricles. Those changes are in particular intensively seen in patients with compromised left ventricular systolic function.

The first attempts to find better ventricular pacing sites and to ascertain more physiological ventricular contraction were made as early as in 1990s. These attempts were inspired by reports from many clinical studies emphasising the deleterious effect of chronic right ventricular pacing and by the fact that active fixation leads were already in the market. In many clinical trials the alternative pacing sites were studied to prove the concept of better systolic function during pacing and/or lower the percentage of pacing in the ventricle. An appropriate pacing site choice, the programming of hysteresis or an adequate atrioventricular delay are of particular importance for the purpose of either avoiding or reducing unfavourable chronic effects of ventricular pacing.

On the basis of numerous literature data, the authors indicate the possibilities to avoid deleterious properties of the chronic right ventricular pacing by the use of currently available pacing modes and pacing leads implantation techniques.

Key words: chronic heart pacing, right ventricle outflow tract pacing, pacemaker syndrome, alternative ventricular pacing sites

(Folia Cardiologica 2015; 10, 6: 410-417)

\section{Piśmiennictwo}

1. Brignole M., Auricchio A., Baron-Esquivias G. i wsp. 2013 ESC Guidelines on cardiac pacing and cardiac resynchronization therapy. The Task Force on cardiac pacing and resynchronization therapy of the European Society of Cardiology (ESC). Developed in collaboration with the European Heart Rhythm Association (EHRA). Eur. Heart J. 2013; 34: 2281-2329.

2. Wiggers C.J. The muscle reactions of the mammalian ventricles to artificial surface stimuli. Am. J. Physiol. 1925; 73: 346-378. 
3. Van Oosterhout M., Prinzen F., Arts T. i wsp. Asynchronous electrical activation induces inhomogeneous hypertrophy of the left ventricular wall. Circulation 1998; 98: 588-595.

4. Lee M.A., Dae M.W., Langberg J.J. i wsp. Effects of long-term right ventricular apical pacing on left ventricular perfusion, innervation, function and histology. J. Am. Coll. Cardiol. 1994; 24: 225-232.

5. Karpawich P., Justice C., Cavitt D. i wsp. Developmental sequelae of fixed-rate ventricular pacing in the immature canine heart: an electrophysiologic, hemodynamic and histopathologic evaluation. Eur. Heart J. 1990; 119: 1077-1083.

6. Adomian G., Beazell J. Myofibrillar disarray produced in normal hearts by chronic electrical pacing. Am. Heart J. 1986; 112: 79-83.

7. Kutarski A. Right ventricular apical pacing sequelae-time for conclusions? Folia Cardiol. 2005; 12: 613-626.

8. Kozłowski D., Kosiński A., Piwko G. i wsp. Morfologiczne podstawy przewodzenia wstecznego u chorych ze stałą komorową (VVI) stymulacją serca. Geriatria 2008; 2: 317-323.

9. Tantengco M.V., Thomas R.L., Karpawich P.P. Left ventricular dysfunction after long-term right ventricular apical pacing in the young. J. Am. Coll. Cardiol. 2001; 37: 2093-2100.

10. Tse H.F., Lau C.P. Long term effect of right ventricular pacing on myocardial perfusion and function. J. Am. Coll. Cardiol. 1997; 29: 744-749.

11. Nielsen J.C., Bottcher M., Nielsen T.T. i wsp. Regional myocardial blood flow in patients with sick sinus syndrome randomized to long-term single chamber atrial or dual-chamber pacing-effect of pacing mode and rate. J. Am. Coll. Cardiol. 2000; 35: 1453-1461.

12. Delhaas T., Arts T., Prinzen F.W. i wsp. Regional fibre stress-fibre strain area as estimate of regional oxygen demand in the canine heart. J. Physiol. 1994; 477: 481-496.

13. Owen C.H., Esposito D.J., Davis J.W. i wsp. The effects of ventricular pacing on left ventricular geometry, function, myocardial oxygen consumption and efficiency of contraction in conscious dogs. Pacing Clin. Electrophysiol. 1998; 21: 1417-1429.

14. Baller D., Wolpers H.G., Zipfel J. i wsp. Comparison of the effects of right atrial, right ventricular apex and atrioventricular sequential pacing on myocardial oxygen consumption and cardiac efficiency: a laboratory investigation. Pacing Clin. Electrophysiol. 1998; 11: 394-403.

15. Badke R.F., Boinay P., Covell J.W. Effects of ventricular pacing on regional left ventricular performance in the dog. Am. J. Physiol. 1980; 238: 858-867.

16. Padeletti L., Santini M., Ravazzi A. i wsp. The 'WHERE' Study: left ventricular performance with RV pacing. Europace 2004; 6 (supl. 1): 127.

17. Nishimura R.A., Gersch B.J., Uliestra R.A. i wsp. Hemodynamic and symptomatic consequences of ventricular pacing. Pacing Clin. Electrophysiol. 1982; 5: 903-905.

18. Mark J.B., Chetham P.M. Ventricular pacing can induce hemodynamically significant mitral valve regurgitation. Anesthesiology 1991; 74 375-377.

19. Twidale N., Manda V., Holliday R. i wsp. Mitral regurgitation after atrioventricular node catheter ablation for atrial fibrillation and heart failure: Acute hemodynamic features. Am. Heart J. 1999; 138: 1166-1175 .

20. Grines C.L., Bashore T.M., Boudoulas H. i wsp. Functional abnormalities in isolated left bundle branch block. The effect of interventricular asynchrony. Circulation 1989; 79: 845-853.

21. Verna R., Cacucci R., Repetto S. i wsp. Regional asynchrony of ventricular correction during pacing studied by Fourier analysis of radionuclide angiography. Cardiac Pacing 1985; 529-534.
22. Boerth R.C., Covell J.W. Mechanical performance and efficiency of the left ventricle during ventricular stimulation. Am. J. Physiol. 1971; 221: 1686-1691.

23. Rosenquist M., Isaaz K., Botvinick E.H. i wsp. Relative importance of activation sequence compared to atrioventricular synchrony in left ventricular function. Am. J. Cardiol. 1991; 67: 148-156.

24. Bedotto J.B., Grayburn P.A., Black W.H. i wsp. Alterations in left ventricular relaxation during atrioventricular pacing in humans. J. Am. Coll. Cardiol. 1990; 15: 658-664.

25. Wilkoff B.L., Cook J.R., Epstein A.E. i wsp.; The DAVID Trial Investigators. Dual-chamber pacing or ventricular backup pacing in patients with an implantable defibrillator. The Dual Chamber and VVI Implantable Defibrillator (DAVID) trial. JAMA 2002; 288: 3115-3123.

26. Sharma A.D., Rizo-Patron C., Hallstrom A.P. Percent right ventricular pacing predicts outcomes in the DAVID trial. Heart Rhythm 2005; 2: 830-834.

27. Jazra C. Kliniczne i ekonomiczne aspekty zespołu stymulatorowego. Folia Cardiol. 1997; 3: 169-175.

28. Barold S.S., Stroobandt R.X., Sinnaeve A.F. Stymulatory serca. Przewodnik ilustrowany. Wydawnictwo Medyczne Urban i Partner, Wrocław 2006: 315-317.

29. Sopolińska E., Krzesiński P., Piotrowicz K. i wsp. Contemporary methods of baroreflex sensitivity assessment in clinical practice. Forum Med. Rodz. 2012; 6: 55-57.

30. Ponikowski P., Banasiak W. Patofizjologiczne mechanizmy omdleń odruchowych. Folia Cardiol. 1999; 6: 4-6.

31. Ellenbogen K.A., Kay G.N., Lan C.P. i wsp. Clinical cardiac pacing, defibrillation and resynchronization therapy. Elsevier Saunders, Philadelphia 2007: 1-1246.

32. Kargul W., Gąsior Z., Herman Z.S. i wsp. Zintegrowana diagnostyka zespołu stymulatorowego. Część III: Badanie echokardiograficzne, elektrokardiograficzne z zapisem przezprzełykowym oraz stężenie surowicze krwi cyklicznego guanozynomonofosforanu. Folia Cardiol. 1999; 6, 2: 167-174.

33. Douglas L.M., Kirkwood F.A., Inder S.A. i wsp. Niewydolność serca. Wyd. 1. Wydawnictwo Czelej, Lublin 2006: 300-301.

34. Kargul W., Gąsior Z., Herman Z.S. i wsp. Zintegrowana diagnostyka zespołu stymulatorowego. Część II: Synchroniczne 24-godzinne badanie EKG metodą Holtera z 24-godzinnym pomiarem ciśnienia tętniczego krwi w diagnostyce zespołu stymulatorowego. Folia Cardiol. Exc. 1999; 6: 43-49.

35. Boon N.A., Frew A.J., Johnston J.A. A comparison of symptoms and intraarterial ambulatory blood pressure during long term dual-chamber atrioventricular synchronous (DDD) and ventricular demand (VVI) pacing. Br. Heart J. 1987; 58: 34-36.

36. Stewart W.J., Dicola V.C., Hartsrone J.W. i wsp. Doppler ultrasound measurement of cardiac output in patients with physiologic pacemakers. Am. J. Cardiol. 1984; 54: 308-312.

37. Andersen H.R., Nielsen J.C., Thomsen P.E. i wsp. Long-term follow-up of patients from a randomised trial of atrial versus ventricular pacing for sick-sinus syndrome. Lancet 1997; 350: 1210-1216.

38. Lamas G.A., Orav E.J., Stambler B.S. i wsp.; Pacemaker Selection in the Eldery Investigators. Quality of life and clinical outcomes in elderly patients treated with ventricular pacing as compared with dual-chamber pacing. Pacemaker Selection in the Elderly Investigators. N. Engl. J. Med. 1998; 338: 1097-1104.

39. Connolly S.J., Kerr C.R., Gent M. i wsp.; Canadian Trial of Physiologic Pacing Investigators. Effects of physiologic pacing versus ventricular pacing on the risk of stroke and death due to cardiovascular causes. N. Engl. J. Med. 2000; 342: 1385-1391. 
40. Link M.S., Hellkamp A.S., Mark Estes III N.A. i wsp. High incidence of pacemaker syndrome in patients with sinus node dysfunction treated with ventricular-based pacing in the Mode Selection Trial (MOST). J. Am. Coll. Cardiol. 2004; 43: 2066-2071.

41. Lamas G.A., Lee K.L., Sweeney M.O. i wsp. Ventricular pacing or dualchamber pacing for sinus-node dysfunction. N. Engl. J. Med. 2002; 346: $1854-1862$.

42. Sweeney M.O., Hellkamp A.S., Ellenbogen K.E. i wsp. Adverse effect of ventricular pacing on heart failure and atrial fibrillation among patients with normal baseline QRS duration in a clinical trial of pacemaker therapy for sinus node dysfunction. Circulation 2003; 107 : 2932-2937.

43. Toff W.D., Skehan J.D., De Bono D.P. i wsp. The United Kingdom Pacing and Cardiovascular Events (UKPACE) trial: United Kingdom Pacing and Cardiovascular Events. Heart 1997; 78: 221-223.

44. Toff W.D., Camm A.J., Shehan J.D. Single-chamber versus dual-chamber pacing for high-grade atrioventricular block. N. Engl. J. Med. 2005; 353: 145-155.

45. Nielsen J.C., Thomasen P.E., Hojberg S. i wsp. On behalf of the DANPACE Investigators. A comparison of single-lead atrial pacing with dual-chamber pacing in sick sinus syndrome. Eur. Heart J. 2011; 32 : 686-696.

46. Sweeney M.O., Shea J.B., Fox V. i wsp. Randomized pilot study of a new atrial-based minimal ventricular pacing mode in dual-chamber implantable cardioverter-defibrillators. Heart Rhythm 2004; 1: 160-167.

47. Baszak J., Koziara D., Kutarski A. Echokardiograficzna ocena hemodynamiki serca w czasie stymulacji drogi odpływu prawej komory w porównaniu ze stymulacją koniuszkowa. Folia Cardiol. 1999; 6: 162-166.
48. Lewicka-Nowak E., Dąbrowska-Kugacka A., Tybura S. i wsp. Right ventricular apex versus right ventricular outflow tract pacing: prospective, randomised, long-term clinical and echocardiographic evaluation. Kardiol. Pol. 2006; 64: 1082-1091.

49. Occhetta E., Bortnik M., Magnani A. i wsp. Prevention of ventricular desynchronization by permanent para-Hisian pacing after atrioventricular node ablation in chronic atrial fibrillation: a crossover, blinded, randomized study versus apical right ventricular pacing. J. Am. Coll. Cardiol. 2006; 47: 1938-1945.

50. Deshmukh P.M., Casavant D.A., Romanyshyn M. i wsp. Permanent, direct His-bundle pacing. A novel approach to cardiac pacing in patients with normal His-Purkinje activation. Circulation 2000; 101: 869-877.

51. Kindermann M., Hennen B., Jung J. i wsp. Biventricular versus conventional right ventricular stimulation for patients with standard pacing indication and left ventricular dysfunction: the Homburg Biventricular Pacing Evaluation (HOBIPACE). J. Am. Coll. Cardiol. 2006; 47: 1927-1937.

52. Doshi R.N., Daoud E.G., Fellows C. i wsp. Left ventricular-based cardiac stimulation post AV nodal ablation evaluation (the PAVE study). J. Cardiovasc. Electrophysiol. 2005; 16: 1160-1165.

53. Moss A.J., Hall W.J., Cannom D.S. i wsp. Cardiac-resynchronization therapy for the prevention of heart-failure events. N. Engl. J. Med. 2009; 361: 1329-1338.

54. Linde C., Abraham W.T., Gold M.R. i wsp.; on behalf of the REVERSE (REsynchronization reVErses Remodeling in Systolic left vEntricular dysfunction) Study Group. Randomized trial of cardiac resynchronization in mildly symptomatic heart failure patients and in asymptomatic patients with left ventricular dysfunction and previous heart failure symptoms. J. Am. Coll. Cardiol. 2008; 52: 1834-1843. 